\title{
十三湖における汽水環境の長期的な 変化要因の検討 \\ A STUDY ON FACTORS RELATED TO LONG-TERM ENVIRONMENTAL CHANGES IN LAKE JUSAN
}

\author{
松根駿太郎 1 - 梅田信 ${ }^{2} \cdot$ 田中仁 ${ }^{3}$ - 佐々木幹夫 ${ }^{4}$ \\ Shuntaro MATSUNE, Makoto UMEDA, Hitoshi TANAKA and Mikio SASAKI \\ 1学生会員 東北大学大学院工学研究科博士前期課程（下980-8579 仙台市青葉区荒巻字青葉6-6-06） \\ 2正会員 博(工) 東北大学准教授 大学院工学研究科（９９80-8579 仙台市青葉区荒巻字青葉6-6-06） \\ 3 フェロー会員 工博 東北大学教授 大学院工学研究科（广9980-8579 仙台市青葉区荒巻字青葉6-6-06) \\ 4 正会員 工博 八戸工業大学教授 工学部環境建設工学科（广031-0814 青森県八戸市大字妙字大開88-1）
}

Lake Jusan is a brackish lake located in the down reaches of Iwaki River system and is one of the most famous places for Corbicula japonica in Japan. The aquatic environment in the lake and the river has long been changing under numerous natural and anthropogenic factors. The former includes changes in meteorological and hydrological systems, while the latter is composed of river improvement works, reclamation for farmland, etc. In this study, we first focused on topographical changes in Lake Jusan caused by the reclamation project completed in 1969 and by sedimentation. The influence on salinity fluctuation in the lake was investigated using computational hydraulic simulation and was found rather small. We then assessed influence of hydrological changes. In 1950s before large dams were constructed in the basin, drought occurred more frequently than 2000s, which seems to have caused excessively high salinity condition for habitation of C. japonica.

Key Words: brackish lake, land reclamation, quasi-3D model

\section{1. 序論}

河川や湖沼の長期的な環境の変化には，流域負荷や湖 内循環の変化が関係している ${ }^{1)}$ ，その原因として，降水 量変化のような自然的影響に加え，人為的影響も考えら れる. 例えば, イシガイ類の生息環境悪化 ${ }^{2}$ や涸沼にお けるヤマトシジミの漁獲量減少引に対する要因として, 河川改修や護岸工事を含めた人間活動の影響が指摘され ている. 本研究で対象とする十三湖は, 岩木川の最下流 部に位置する汽水湖であるが, 河口導流堤の建設や上流 域の干拓，あるいは岩木川の河川整備や上流でのダム建 設等，この数十年間のうちに様々な影響による变化を受 けている.

十三湖は，国内でも有数のヤマトシジミの漁場として 知られており, 水産業は地域の主要な産業の一つである. ヤマトシジミの生息は，当然のことながら，汽水条件4,5) や水質条件6,7)あるいは底質条件 ${ }^{8)}$ の影響を受ける。ただ し，ヤマトシジミの漁獲量に関しては, 漁獲状況や養 殖・放流といった漁業方法の影響も大きいため，一概に
議論することが難しい，例えば，十三湖の経年的な漁獲 高の変化を見ると，非常に大きな変動があったことが分 かっている9 . 昭和35年から昭和50年は，漁獲規制がな く最大では年間3,000トンに達することもあった。しか し, この乱獲に加え異常渇水等が発生し, この後の10年 程度は漁獲量が低迷した，それ以降は，資源管理が徹底 され年間2,000トン程度で維持している.

ヤマトシジミの生息や漁獲の中長期的な変遷を考える 上では, 水質, 底質が悪化したから, あるいは乱獲した からであるといった単純な議論ではなく, 例えば当時の 水環境がどのようであり，現在とどのように異なるかを， 実測データや数值シミュレーション等に基づいて定量的 に論じていく必要があると考えられる．また，将来的な 河川・湖沼管理の方針を検討寸る際には，気候変動等の 時間的に変化する外部環境要因を考慮した予測に基づい た議論も必要になろうと考えられる。

このようなことから，本研究では，1950年代頃までの 十三湖の地形的，水文的な環境についてのデータを整 理・解析し，現在（2000年代）との差違について検討し 


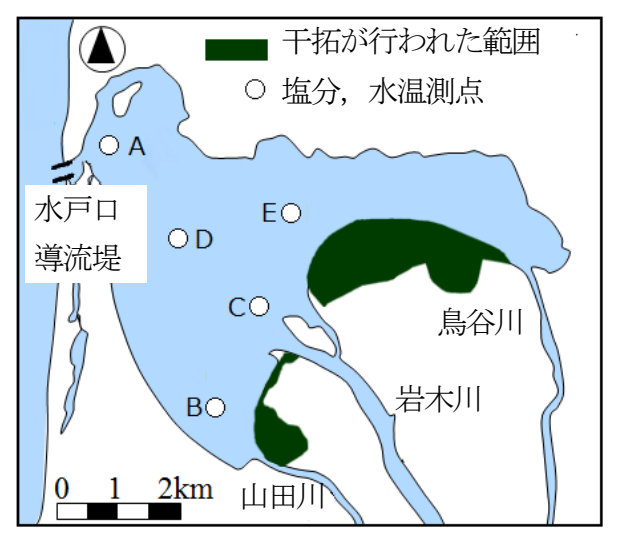

図-1 十三湖平面図

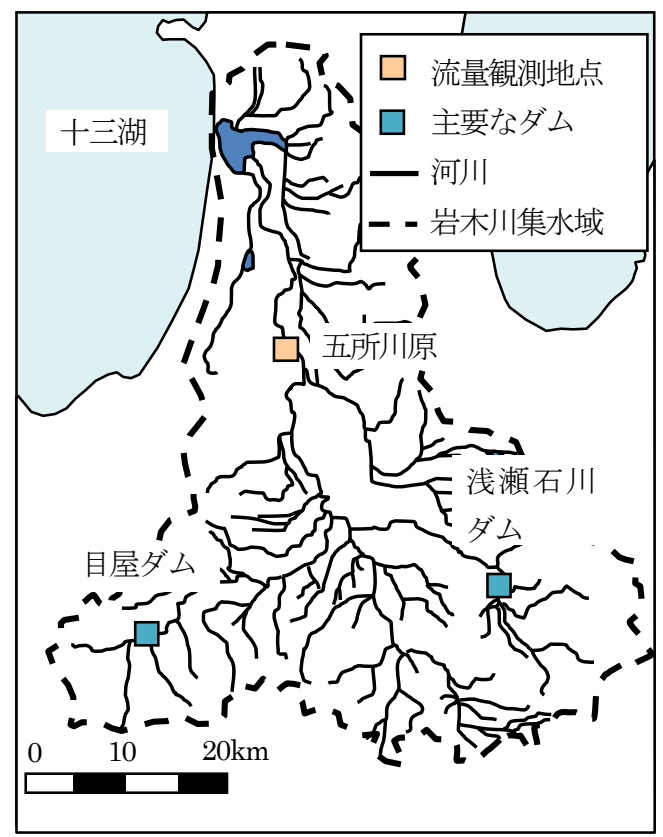

図-2 岩木川流域の概略

た. その上で，ヤマトシジミの生息に大きく関与すると 考えられる湖内の塩分環境について, 流動数值シミュ レーションに基づいて，過去と現在の状況について比較 検討を行った.

\section{2. 研究対象}

十三湖は，青森県津軽半島北西部に位置し，日本海に 面している汽水湖である. 図-1に十三湖の平面図を示す. 湖の北西部において十三湖と日本海が接続されており, この地点を水戸口という. かつて水戸口は閉塞と開削を 繰り返してきたが，1946年に現在の位置に導流堤が竣工 したことにより，閉塞することはなくなっている，十三 湖の中心部の最大水深は約 $2 \mathrm{~m}$ と浅く, 湖の容積に対し て集水面積が大きい，そのため，湖水の平均滞留期間が 1 日程度と非常に短い。十三湖への流入河川は岩木川, 山田川，鳥谷川等であるが，岩木川が全集水面積の約 78\%を占める. 図-2に示寸ように, 岩木川流域の上流に

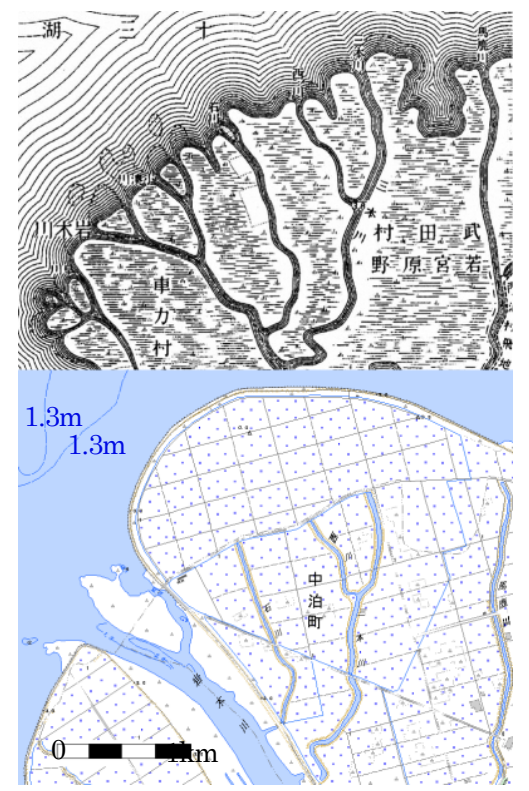

図-3 岩木川河口の比較（上図 : 1917年, 下図 : 現在)

は目屋ダム（1960年竣工），浅瀬石川ダム（1988年竣工） といった2つの大きなダムがある.

十三湖干拓建設事業は, 十三湖湖面 $2.37 \mathrm{~km}^{2}$ 及び岩木 川下流域の湿地带 $8.48 \mathrm{~km}^{2}$ の範囲で行われた. 1948年に 着工し, 湖口の汀線を大きく囲むような堤防（囲繞堤） が建設され，1969年に干拓が完了した. 図-3に，1917年 の地形図 ${ }^{10)}$ と現在の岩木川河口部分 ${ }^{11)}$ を示寸. 干拓によ り鳥趾状の河口が直線化され，網目状に分かれていた岩 木川は，岩木川本川から直接流入するようになっている.

\section{3. 解析方法}

\section{（1）地形変化}

明治時代の測量地図（岩木川平面図）を用いて，過去 の十三湖の地形を解析した。岩木川平面図は，岩木川の 改修にあたって，1911年から1912年に掛け，内務省によ り測量，作成されたものである．全体では，岩木川の中 流部までを含む，河口から約 $50 \mathrm{~km}$ までの範囲で制作さ れたものだが，本研究では十三湖を含んだ最下流部のみ を利用した。縮尺は 3000 分の 1 ，十三湖内に引かれた等

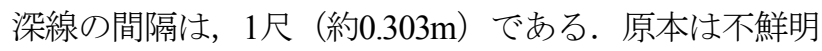
であったことから, 清野らがトレースした十三湖内等深 線の電子画像息を用いた。 この等深線のトレース画像か ら，デジタル化ソフトウエア（GoldenSoftware社製 Digger）を用いて，湖岸および等深線をデジタル化した. この等深線データについて, 湖内の深度情報を空間内 插した格子データ（格子間隔 $40 \mathrm{~m} ）$ を作成して, 深度ご との湖底面積や容積を計算し, 標高一湖容量曲線を作成 した。なお，深度の空間内挿方法は，クリギング法，動 径基底関数法, 最小曲率法等種々の手法を試行した上で, 元の等深線と対応が最も良かった最近傍法を採用した.

現在の地形は，国土交通省青森河川国道事務所が， 2006年に実施した十三湖の深浅測量結果を用いて解析を 
行った.この測量では，十三湖内の全域で概ね $200 \mathrm{~m}$ 間 隔の測線が設定されて計測された。これについてはクリ ギング法により空間内挿した格子データ（格子間隔 $40 \mathrm{~m}$ ) を作成して，標高一湖容量曲線を作成した，なお，次 節で述べる湖水流動計算の計算格子は同様の方法で，格 子間隔 $200 \mathrm{~m}$ の格子データを作成した.

\section{（2）湖水流動の解析モデル}

十三湖内の汽水環境（塩分変動）の解析は，準3次元 の流動解析モデルを用いて行った. 本モデルは梅田ら ${ }^{5}$ によって十三湖に適用されており, 再現性が確認されて いる. 支配方程式である運動方程式は，以下のようにな る.

$$
\begin{gathered}
\frac{\partial u}{\partial t}+u \frac{\partial u}{\partial x}+v \frac{\partial u}{\partial y}+w \frac{\partial u}{\partial z}=-g \frac{\partial \eta}{\partial x}+A_{x} \frac{\partial^{2} u}{\partial x^{2}}+A_{y} \frac{\partial^{2} u}{\partial y^{2}} \\
+A_{z} \frac{\partial^{2} u}{\partial z^{2}}+\frac{\tau_{w x}-\tau_{b x}}{\rho_{0}}+\frac{g}{\rho_{0}} \frac{\partial}{\partial x} \int_{z}^{\eta} \rho d z+f v \\
\frac{\partial v}{\partial t}+u \frac{\partial v}{\partial x}+v \frac{\partial v}{\partial y}+w \frac{\partial v}{\partial z}=-g \frac{\partial \eta}{\partial y}+A_{x} \frac{\partial^{2} v}{\partial x^{2}}+A_{y} \frac{\partial^{2} v}{\partial y^{2}} \\
+A_{z} \frac{\partial^{2} v}{\partial z^{2}}+\frac{\tau_{w y}-\tau_{b y}}{\rho_{0}}+\frac{g}{\rho_{0}} \frac{\partial}{\partial y} \int_{z}^{\eta} \rho d z-f u
\end{gathered}
$$

ここで, $t:$ 時間, $x, y:$ 水平方向座標, $z$ : 鉛直上向き 座標, $\{u, v, w\}:\{x, y, z\}$ 方向の流速, $\eta$ : 自由 水表面の静水面からの高さ, $g$ : 重力加速度, $\rho:$ 水の 密度, $\rho_{0}$ : 水の平均密度, $A_{x}, A_{y}, A_{z}: x, y, z$ 方向の渦 動粘性係数, $\tau_{w x}, \tau_{w y}: x, y$ 方向の風による水面せん断応 力, $\tau_{b x}, \tau_{b y}: x, y$ 方向の底面せん断応力, $f:$ コリオリ パラメータである。

連続式については, 水深方向に積分し, 水位変動の計 算に用いた.

$$
\frac{\partial \eta}{\partial t}=\frac{\partial}{\partial x}\left[\int_{-H}^{\eta} u d z\right]+\frac{\partial}{\partial y}\left[\int_{-H}^{\eta} v d z\right]
$$

ここで $H$ は底面の鉛直座標である.

水温と塩分は以下の移流拡散方程式より求めた.

$$
\begin{aligned}
& \frac{\partial \phi}{\partial t}+u \frac{\partial \phi}{\partial x}+v \frac{\partial \phi}{\partial y}+ w \frac{\partial \phi}{\partial z}= \\
& K_{x} \frac{\partial^{2} \phi}{\partial x^{2}}+K_{y} \frac{\partial^{2} \phi}{\partial y^{2}}+K_{z} \frac{\partial^{2} \phi}{\partial z^{2}}+S_{\phi}
\end{aligned}
$$

ここで, $\phi$ : 塩分・水温, $K_{x}, K_{y}, K_{z}: x, y, z$ 方向の渦 動拡散係数である. S 気象条件による水面を通じた熱収支を考慮した。

\section{（3）流動計算の条件}

主要な計算条件は，既往研究5),13) と概衩同様に与えた。 計算対象領域は $7.4 \mathrm{~km} \times 5.8 \mathrm{~km}$ で水平計算格子間隔 $200 \mathrm{~m}$, 鉛直格子間隔 $0.1 \mathrm{~m}$ とた。計算期間は，6月中旬から 10 月中旬までとした。この期間とした理由は, 序論で記し たとおり，湖内でのヤマトシジミの生息状況が，筆者ら の関心事項であることが大きい，計算対象期間は，概ね
夏季であるが，既往研究14)等によれば，この間にヤマト シジミの産卵期が含まれる，さらに，産卵および餒化に

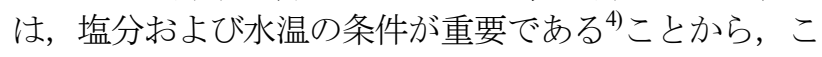
の時期の汽水環境の解析が重要と考えた.

各種の境界条件は，以下のように設定した。河川流入 量は，五所川原地点で国土交通省により計測された流量 に対して，十三湖地点との流域面積比を乗じて十三湖へ の流入量とした，一方，水戸口通過流量 $Q_{M}$ は，十三湖 水位の実測值 $h$ と河川流入量 $Q_{R}$ を用いて, 湖水の連続条 件である以下の式(5)から推定した.

$$
Q_{M}=Q_{R}-A_{L} \frac{d h}{d t}
$$

なお $A_{L}$ : 十三湖面積である. 海水塩分は，水戸口にお ける過去の計測結果から，33psuの一定值を与えた.

過去の環境における湖水流動の計算条件は, 以下のよ うな考え方で設定した. 検討条件の一つ目は, 干拓等に よる湖地形の変化の影響を調べるものである. 湖の水深 条件は, 岩木川平面図の等深線から作成したものを用い た. その他の条件 (河川流量, 湖水位) については, 現 在（2008年実測）の值に揃えて検討をした. ただし，地 形改変前の岩木川の河口は, 図-3に示寸ように網目状に 分散している. この条件を模擬するため, 岩木川の流入 を6力所に分散させた．各流入部からの流量については, それぞれの川幅が概ね等しいことから流量も概ね等しい と判断し6等分とした.

検討条件の二つ目は，岩木川の流況変化による影響を 把握するためのものである. 干拓工事が完了する前の 1950年代（最も過去の流量データが得られた1953年から 1959年）の岩木川の流況と2000年代（2001年から2010年） の流況とを示したのが図-4であり，両年代では，非常に 大きな差があることが分かった．1950年代には，五所川 原地点での流量が $10 \mathrm{~m}^{3} / \mathrm{s}$ 以下となる日数が, 平均で 40 日 程度あった．一方2000年代は，2007年に生じた数日を除 き $10 \mathrm{~m}^{3} / \mathrm{s}$ 以下となることがなかった。 このようなことを 踏まえ, 過去と現在の流量条件も含めた検討も行った. 計算は, 次の全4力年で実施した。過去の条件として, 1954年（低水流量と渴水流量が最も小さい年）と1957年 （1950年代の中で平均的な流況の年）を選定した．現在 条件には，2007年と2008年を選定した。この2年間は， 既往検討)でも対象にされたことから，各種の実測計算 条件が最もよく整っており, 再現性についても確認され ているためである.

1954年と1957年の流動計算で，湖地形は現実に即する よう干拓前の条件を与えた. 河川流量は，2000年代は時 間流量データを用いたのに対して，1950年代は日流量を 用いた. ただし, 本研究での計算の趣旨は, 前段落に記 したように低水時の流況の変化による影響を中心とした 検討としているため, 時間流量と日流量の差は, 大きく 効かないと考えられる. 一方, 湖水位はデータが得られ なかったため，計算期間の天文潮位を計算し，これを湖 

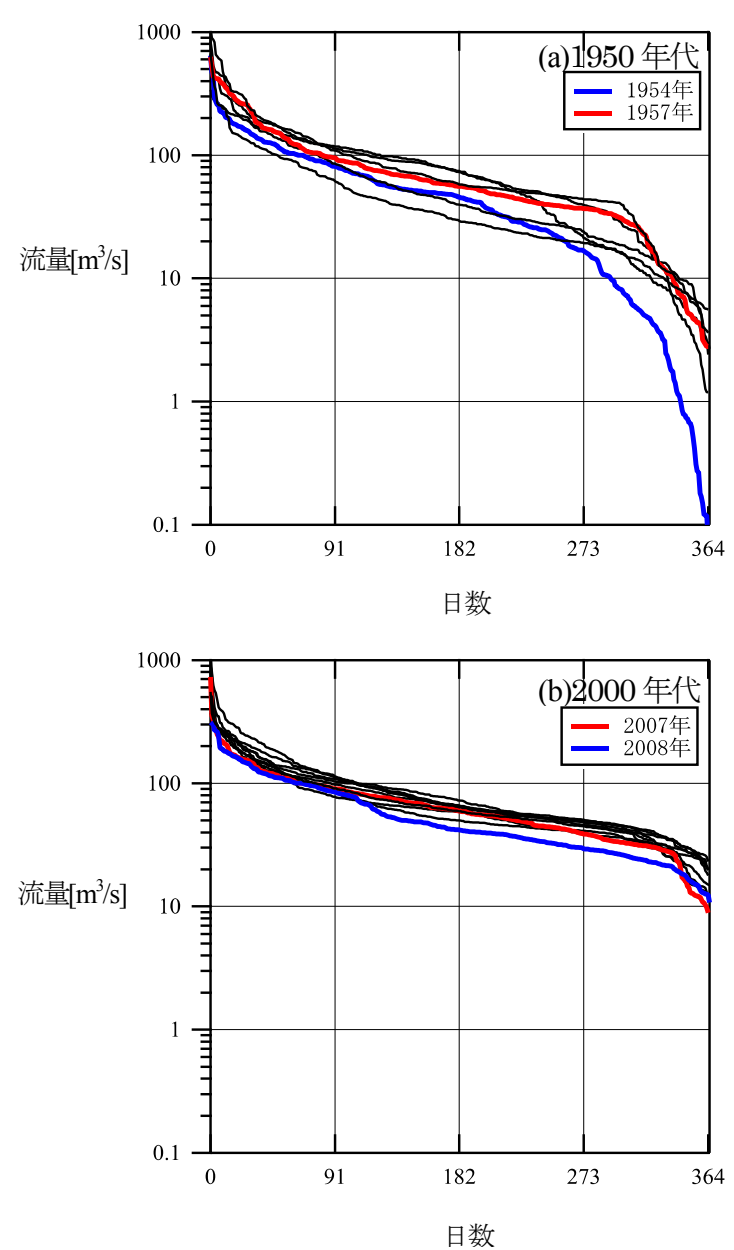

図-4＼cjkstart五所川原地点における (a) 1950年代（1953～1959年）と (b) 2000年代（2001 2009年）の岩木川流況の比較

水位として与えた. 十三湖は, 図-1のように延長数百m のごく短い水戸口を挟んで日本海に面しているため, 概 水潮位に等しい湖水位変動をする。したがって，推算潮 位を湖水位の変動とすることは，概水妥当な仮定である と考えられる。

\section{4. 解析結果}

\section{（1）地形変化}

岩木川平面図から再現した地形データと2006年の深浅 測量結果を比較した結果，比較的顕著な差として，岩木 川流入部の鳥趾状の地形が直線化されたことの他に，水 戸口付近における等深線の後退が見られた（図-5) . こ れは, 導流堤の竣工により水戸口付近における湖水と海 水の交換速度が増大し, 底質の洗掘が進んだ影響がある と考えられる. 十三湖中心部の湖底標高は, 明治時代が 約- $2.1 \mathrm{~m}$, 現在が約-1.9mであり，現在の方がわずかなが ら浅くなっていた。 これは河川からの流入土砂が湖底に 堆積したためであると考えられる.

図-6に地形図から作成した標高一湖容量 (H-V) 曲線 を示す，明治時代からほとんど変化は見られないが，深

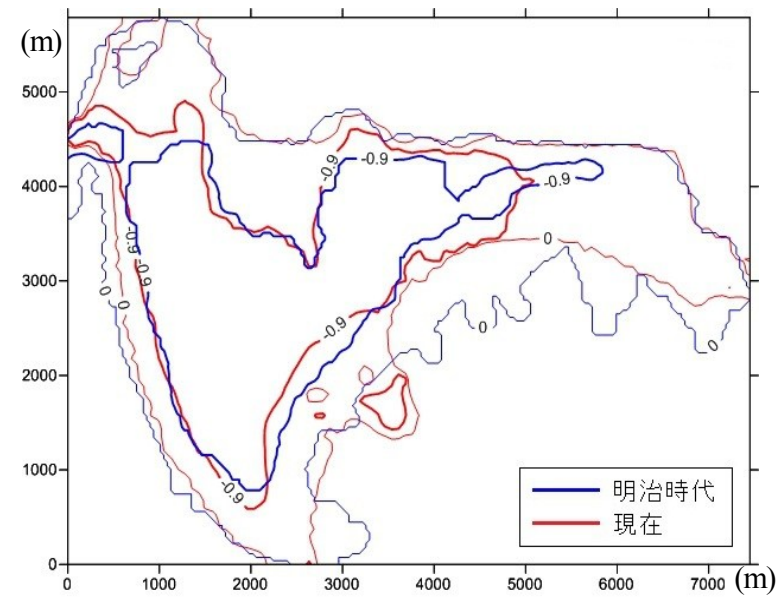

図-5 明治時代（水戸口建設と干拓の前） と現在（2006 年) の湖岸線および標高-0.9mの等深線の比較

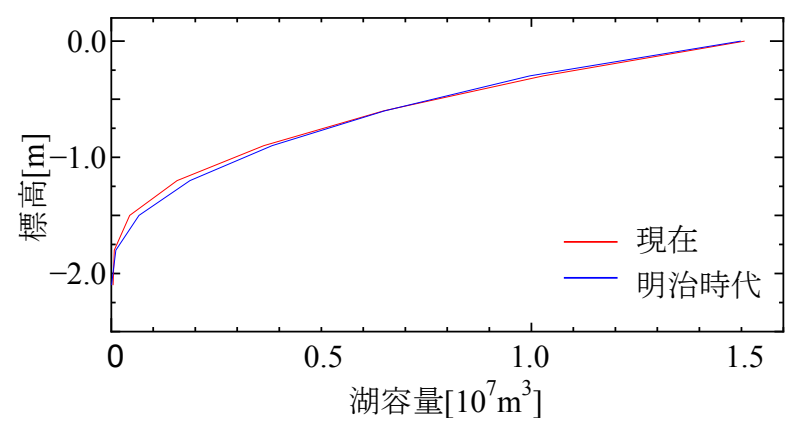

図-6 明治時代と現在の測量結果に基づく十三湖の標高一湖 容量 $(\mathrm{H}-\mathrm{V})$ 曲線

部と浅部にそれぞれ，堆砂と干拓によると考えられる差 があった. 浅部の差は干拓による容積変化に対応し, 深 部における差が，約100年間の土砂堆積量に対応するも のと仮定して, 深部における土砂堆積量を算出したとこ ろ約 $6.6 \times 10^{4} \mathrm{~m}^{3}$ が得られた。この值は藤田ら ${ }^{12}$ による岩 木川の掃流砂量調査の結果に基づいた推定值の約 0.7 倍 となった．かなり大雑把な計算ではあるが，両者は概ね 一致する結果となったことから，この值は妥当な推定值 と考えられる.これを比堆砂量に換算すると $2.7 \times 10^{-1} \mathrm{~m}^{3}$ $/ \mathrm{km}^{2} /$ 年となった. これは, 同じく青森県の太平洋側に ある馬淵川河口 (八戸港) の平均的な堆砂量 ${ }^{15}$ から推 定した值の約 $170 \mathrm{~m}^{3} / \mathrm{km}^{2} /$ 年や石狩川での推定值 ${ }^{16) て ゙ あ る ~}$ 35 56 $\mathrm{m}^{3} / \mathrm{km}^{2} /$ 年と比較すると非常に小さい. この理由 の一つとして, 五所川原よりも下流の河道内における堆 積が大きい(2)ことがあると考えられる。

\section{（2）地形改変と塩水流動}

図-7に，2008年の流量条件に対して実施した計算に より, 十三湖の地形変化に基づく塩分変動の相違を示す. 過去の地形条件の計算結果では, 現在と比較して, 浅部 における塩分がわずかに高く（図-7(b)，(c)），深部で 低下（図-7(d)）している時期があるものの, 湖内塩分 の変動に大きな変化は無かった. 浅部での塩分が, 潮汐 


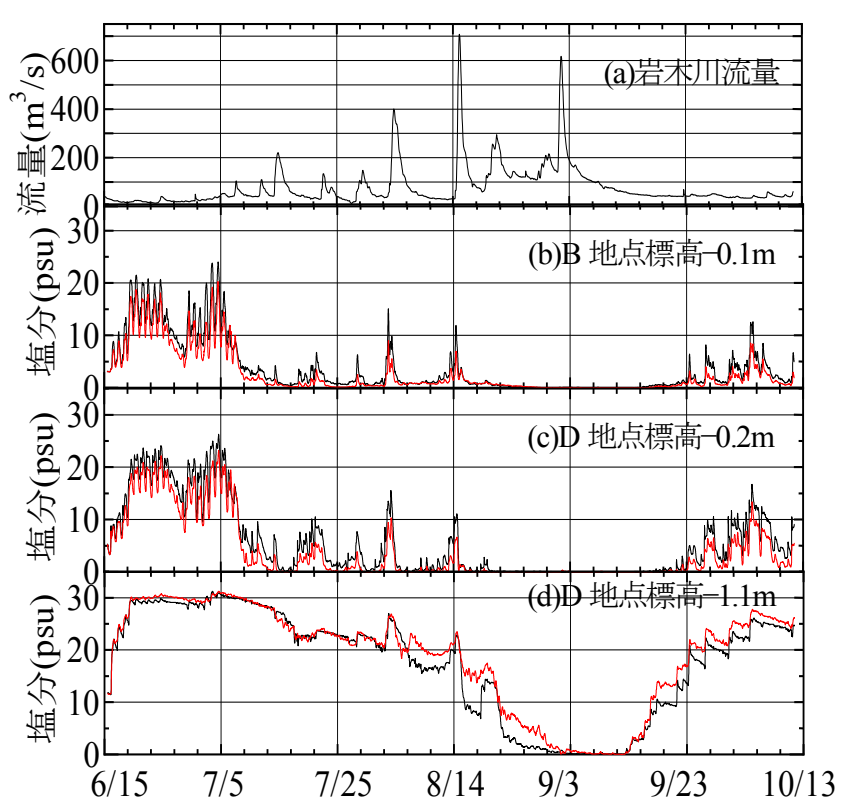

\section{—改変前の地形による塩分の計算值} 現在の地形による塩分の計算值

図-7 2008年夏期の岩木川流量および湖内塩分の計算結果

に対応して大きく変動することや，湖心付近の底層（D 地点標高-1.1m）において塩水が滞留しやすいという傾 向も現在の状況) と変わらなかった. これは, 先述のよ うに干拓や堆砂が十三湖の湖水容量にほとんど影響を与 えなかったためであると考えられる.

\section{（3）流況変化と塩水流動}

流量条件についても変化させ，過去（1954年，1957 年）と現在（2007年，2008年）の岩木川流量を適用した 塩分変動の計算結果を図-8から図-11に示寸.1954年

（図-8）と1957年（図-9）の計算値には，渴水と出水の 影響が強く表れており，河川流量の影響が湖内塩分に対 して大きな影響を与えることが分かった。このような塩 分への影響に関して，ヤマトシジミの生息環境としての 観点から, 流況の変化と合わせて以下で議論する.

ヤマトシジミが水温に関係なく長期間生存可能な塩 分濃度範囲は1.5〜22psuであるとされている8 ${ }^{8)}$. 1954年 は，塩分が7月中旬から8月下旬の長期間にわたって海水 塩分（33psu）に近い值を示した．そのため，この年の 夏季はヤマトシジミの大量整死が起こった可能性がある 1950年代の岩木川（五所川原地点）の渴水流量は，平均 で $4.7 \mathrm{~m}^{3} / \mathrm{s}$ であったが，1954年は特に低く，わずか 0.42 $\mathrm{m}^{3} / \mathrm{s}$ だった．1957年は，6月下旬から7月上旬にかけ て流量 $10 \mathrm{~m}^{3} / \mathrm{s}$ 以下の日が続いており，同期間では塩分は 海水塩分に近い值を示している．ただし，7月上旬以降 は出水が繰り返されたため, 湖内塩分は低下した。

このような1950年代の状況に対し，1960年以降は，恐 らく目屋ダム供用の効果から流況が安定し，1960年代の

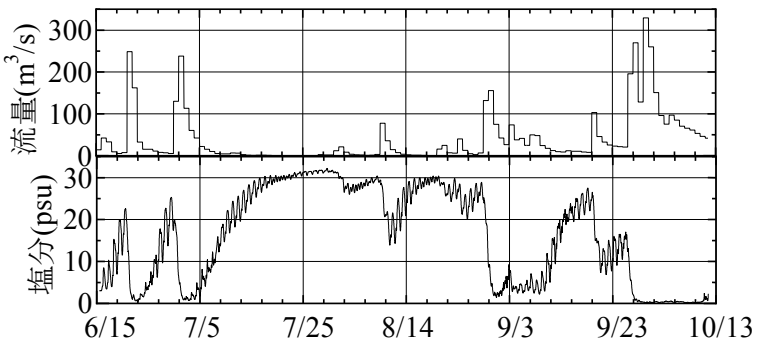

図-8 1954年夏期の岩木川流量およびB地点標高-0.1mににおけ る湖内塩分の計算結果

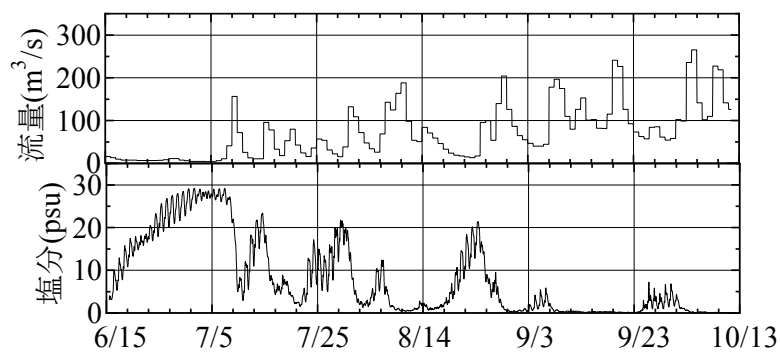

図-9 1957年夏期の岩木川流量およびB地点標高-0. 1mににおけ る湖内塩分の計算結果

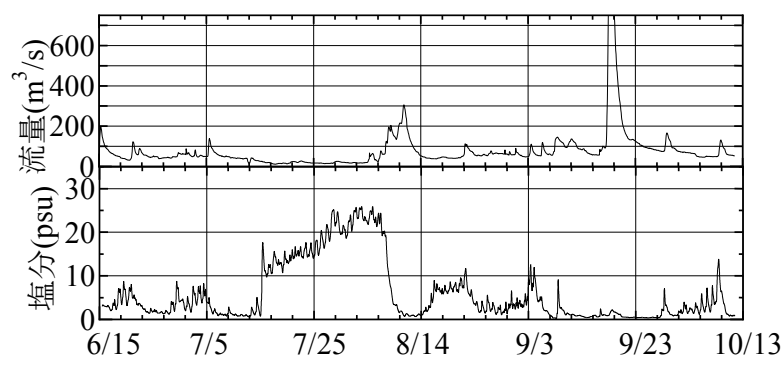

図-10 2007年夏期の岩木川流量およびB地点標高-0.1mににおけ る湖内塩分の計算結果

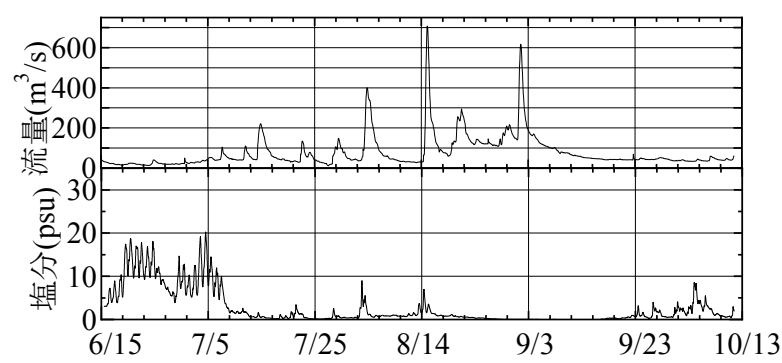

図-11 2008年夏期の岩木川流量およびB地点標高-0. 1mににおけ る湖内塩分の計算結果

渇水流量は平均で $16.4 \mathrm{~m}^{3} / \mathrm{s}$ まで上昇した（2000年代は $21.4 \mathrm{~m}^{3} / \mathrm{s}$ ）。しかし，2007年は，7/15に流量が $15 \mathrm{~m}^{3} / \mathrm{s}$ 程度 になるとともに塩分が急激に上昇するイベントが見られ た７月17日，18日は，2000年代でこの期間だけとなる $10 \mathrm{~m}^{3} / \mathrm{s}$ 未満にまで流量が低下寸るような厳しい渴水であ り，結果として高塩分の日が続いた．2007年はヤマトシ ジミの整死が起こったことが，地元から報告されており， 高塩分が斃死を引き起こしたと推測される. 2008年につ いては，まとまった出水が何度も起こっており，低塩分 
の日が続いた。

以上の結果から，十三湖の塩分環境に対して，岩木川 の流況の影響が大きいことが示された．1950年代は，図 -4に見られるように，年ごとの流況変動が大きく，また 渇水流量がかなり低かった。 そのため, 湖内の塩分から 考えると，ヤマトシジミの生息に対しては，やや過酷な 環境だったと考えられる. 一方，2000年代には，流域の ダム建設による効果もあると考えられるが，流況が安定 し渇水の頻度が減少している.しかし，2000年代でも， 渇水が発生すると高塩分の日が続き, ヤマトシジミ斃死 の原因となる可能性があることが分かった.

\section{5. 結論}

本研究においては，明治時代の測量地図である岩木川 平面図のデジタル化および数值シミュレーションを行う ことにより, 地形改変前の十三湖と現在の十三湖の地形 相違と水環境の相違を明らかにした。また，岩木川の流 況変化の考察を行い，1950年代と2000年代の岩木川流量 を用いてシミュレーションを行うことにより，流況の変 化による湖内の塩分条件の変化を示した，以下に，本研 究で得られた主要な結論を示す.

1) 十三湖は，この約 100 年間で上流域の干拓等地形の 人為改変があったものの, 堆砂を含めた湖水容量の 変化は非常に小さい.

2) 干拓は，岩木川からの流入条件等上流部の地形を大 きく変えたが，湖内の塩分環境に対する影響は小さ かったただし，干拓による湖岸線の単調化や干潟 面積の減少などが，湖内生態系への影響を及ぼした 可能性については引き続き検討が必要である.

3） 1950 年代の岩木川流量の条件を用いて湖内塩分の計 算を行った．低水時の流況が，現在（2000年代）と 大きく異なっていたため, 現在よりも常時の塩分が かなり高いことが推定された。この流況変化は，気 候的な変化による降水の変化およびダムの建設等に よる流量の変化によるものと考えられる.

4) したがって，岩木川上流のダム群や灌䄽用水を含め た流域内の水運用を適切に行い，夏季の渇水を防ぐ ことができれば，十三湖内の高塩分によるヤマトシ ジミの斃死を防止できる可能性があると考えられる。

謝辞：本研究は，JSPS科研費21360230および河川砂防技 術研究開発（河川生態, 代表 : 佐々木幹夫）の援助によ り実施された。また，国土交通省青森河川国道事務所か ら, 岩木川平面図（写し），十三湖周辺地図および湖内 深浅測量データの提供を受けた。 九州大学清野聡子准教 授からは，岩木川平面図（十三湖部分）をトレースした
電子画像の提供を受けた．記して謝意を表する.

\section{参考文献}

1) 福島武彦, 川村修平, 恩田裕一, 今井章雄, 松重一夫 : 霞ヶ浦, 諏訪湖における底質長期変化と栄養塩収支, 水環 境学会誌, Vol.28, No.5, pp.313-319, 2005.

2) 根岸淳二郎, 萱場祐一, 塚原幸治, 三輪芳明 : 指標・危急 生物としてのイシガイ目二枚貝 : 応用生態工学, Vol.11, No.2, pp.195-211, 2008.

3) 中村幹雄編著 : 日本のシジミ漁業, p.266, たたら書房, 2000.

4) 鶴田泰士, 石川忠晴, 西田修三, 成田舞, 藤原広和 : 小 川原湖におけるヤマトシジミの繁殖環境について, 土木学 会論文集，No.705/II-59，pp.175-187， 2002.

5) 梅田信, 小西絵里子, 田中仁, 佐々木幹夫 : 浅い汽水湖にお ける塩分変動解析, 水工学論文集, 第54巻, pp.1423-1428, 2010.

6) 中村由行, 井上徹教, 柳町武志, 石飛裕, 神谷宏, 嘉藤 健二, 山室真澄 : 汽水湖沼沿岸部における水温, 水質構 造の日周変動一鉛直対流循環が二枚貝生態系に及ぼす影 響一, 水工学論文集, 第41 巻, pp.469-474, 1997.

7) Atas Pracoyo, Makoto Umeda, Hitoshi Tanaka, Mikio Sasaki and Masayasu Nagasaki: Factors effecting on mortality rate of Corbicula japonica in Lake Jusan, Japan, Journal of Japan Society of Civil Engineers, Ser. B1 (Hydraulic Engineering), Vol. 68, No.4, I_295-I_300, 2012.

8) 中村幹雄 : 宍道湖におけるヤマトシジミと環境の相互関 係に関する生理生態学的研究，北海道大学博士論文，1997.

9) 中村幹雄編著 : 日本のシジミ漁業, p.90, たたら書房, 2000

10)国土交通省青森河川国道事務所提供 : 十三湖周辺地図（大 正6年) .

11)電子国土Webシステム. (http://portal.cyberjapan.jp/)

12)河川生態学術研究会岩木川研究グループ: 岩木川の総合研 究, 2012.

13)Atas Pracoyo, 梅田信, 田中仁, 佐々木幹夫 : 汽水環境解析 のための十三湖水戸口流量の推定方法に関する検討, 土木 学会論文集B2（海岸工学），Vol. 66, pp.981-985，2010.

14) Atas Pracoyo, 梅田信, 田中仁, 佐々木幹夫, 長崎勝康 : 十 三湖におけるヤマトシジミ産卵期の塩分・水温と稚貝生息 数に関する検討，土木学会論文集B2（海岸工学），Vol. 67, No.2, pp.1001-1005, 2011.

15)片寄誠，村上敏幸，山田貴裕，原信彦：八戸港内の埋没実 態と予測モデルの構築, 海岸工学論文集, 第54巻, pp. 431435, 2007.

16)清水康行, 嵯峨浩, 早川博, 品川守 : 石狩川の土砂流出に 関する研究，水工学論文集，第42巻，pp.1039-1044， 1998

(2012. 9. 30受付) 